\title{
The Journal of Values-Based Leadership
}

Volume 13

Issue 1 Winter/Spring 2020

Article 3

January 2020

\section{What Do We Really Mean By Good Leadership?}

\section{Tom Karp}

Kristiania University College, tom.karp@kristiania.no

Follow this and additional works at: https://scholar.valpo.edu/jvbl

Part of the Leadership Studies Commons

\section{Recommended Citation}

Karp, Tom (2020) "What Do We Really Mean By Good Leadership?," The Journal of Values-Based Leadership: Vol. 13 : Iss. 1 , Article 3.

DOI: https://doi.org/10.22543/0733.131.1300

Available at: https://scholar.valpo.edu/jvbl/vol13/iss1/3

This Editorial is brought to you for free and open access by the College of Business at ValpoScholar. It has been accepted for inclusion in The Journal of Values-Based Leadership by an authorized administrator of ValpoScholar. For more information, please contact a ValpoScholar staff member at scholar@valpo.edu. 


\title{
What Do We Really Mean By Good Leadership?
}

\author{
TOM KARP, OSLO, NORWAY
}

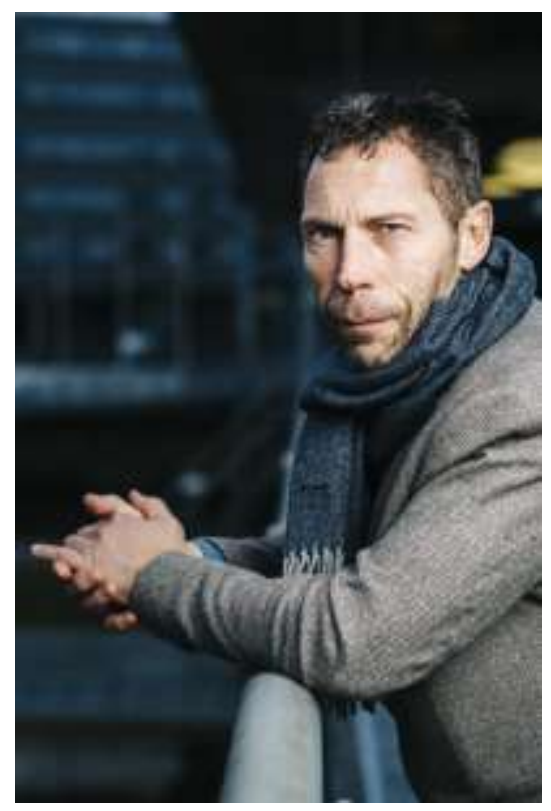

\section{Introduction}

The concept of leadership is certainly vague and one that many scholars try to turn into something more distinctive, that is, into an "it" concept (Alvesson, 2019). After a century of leadership research, the field is still struggling for academic recognition. No generally accepted universal theories can be tested and developed; methodologies and analytical techniques are not always sufficiently rigorous. We often assume that leadership is important and that it ought to be so. However, it is also possible to argue that leadership is not essential in our complex society and that leadership does not contribute to solving major societal problems. None of the UN's Sustainable Development Goals (2015) mentions leadership as a means for achieving a goal. The same applies to efforts to tackle societal challenges at national and local levels - the potential contribution of leadership is rarely mentioned. It may even be claimed that leadership creates problems and hinders development. This applies in particular to what we might classify as poor leadership - based on egoism, immorality, lack of judgement, dominance, and destructiveness.

Yukl (2013, p. 422) is not objective but states his case clearly: Leadership is important. Effective leadership is essential for coping with the growing social, economic and environmental problems confronting the world. The annual report of the World Economic Forum (2016) predicts that the ability to lead people will become ever more significant in the workplaces of the future. It justifies this prediction by citing the increasingly complex challenges faced by society at local and wider levels. We may, therefore, also argue that leadership is important for solving problems and taking forward groups, organisations, and society. If there is one factor that can really contribute to solving major problems, it is good leadership - not just leadership, but good leadership. It is not leadership in isolation but a tool for cooperation, innovation, and change. The greater the challenges, the greater the need for leadership (Karp, 2010). This is not leadership in the sense of grandiose actions but all the small steps that take place every day to promote progress and development. Accordingly, I hence argue that good leadership can make a difference; good leadership is most likely imperative. Nonetheless, what do we really mean by "good"?

\section{The "Goodness" Criterion}

The goodness criterion in leadership is part of the legacy of classical philosophy which is normative in its description of leadership. Most of the classical philosophers in both the West and the East lacked an instrumental understanding of leadership. For them, leadership was not about methods, techniques, and tools but was part of a greater whole and about being a good person in a good society. Generally, we can say that philosophers have been and are concerned with two forms of goodness. First, leaders should possess good characteristics. Philosophers assume that if a leader has good characteristics, this 
will result in good actions. In other words, they assume a causal link between good characteristics and good actions. The characteristics that they view as important vary to some extent, but generally, these are associated with maturity and compassion (Forsth, 2002). In the words of Seneca (1982, p. 73), When we act on the basis of the best of all human characteristics, that is humanity. Plato (2007) emphasised that leaders should not allow their own self-interest to take priority over the demands of the art of leadership. When a leader exercises leadership in accordance with the demands of the art of leadership, then he or she is a genuine leader. The Eastern philosophers express similar ideas: according to Sun Tzu, Leadership is a matter of intelligence, trustworthiness, humaneness, courage, and sternness (Cleary, 1989 p. 45).

Consequently, those who lead must possess good qualities and skills that enable them to excel in their jobs. This is clearly expressed in the virtues of antiquity, which were further developed in the Middle Ages, when philosophical and theological ideas merged. Similar virtues may also be found in the Eastern cultures, most clearly expressed in the Samurai tradition, characterised by such professed virtues as wisdom, justice, courage, and moderation. In the Christian doctrine, the theological virtues of faith, hope, and love are often added to the aforementioned virtues. The virtues should help individuals understand and realise their own potential and promote the development of their character, enabling them to contribute to the good of the community. Thus, according to classical philosophy, good leaders should be able to develop themselves and others and show that they are trustworthy (Brunstad, 2009). However, Machiavelli (1992) stated that a leader does not necessarily have to possess such qualities, but should be able to give such an impression.

When a good leader possesses the right mix of virtues, then followership will be a voluntary process wherein the leader will not have to resort to the use of power and coercion. Plato (2007) distinguishes between the tyrannical leader who rules through fear and the type of leader who people follow voluntarily; he claims that only the latter form constitutes true leadership. The writings of Chinese Zen masters Miaoxi and Zhu-an express similar thoughts: When you are honorable, the community obeys even if you are not stern .... This is more than ten thousand times better than those who hold on by authoritarian power and those who cannot help following them, oppressed by compulsion (Cleary, 1990, verse 27). In contrast, advocating pragmatism, as well as instrumentalism, Machiavelli (1992) claimed that leadership also needs to be based on fear. However, it should be noted here that Machiavelli's primary target audiences were those who sought power - not those who had it.

The second form of goodness with which the classical philosophers were concerned was goodness in relation to purpose; leadership should create a good society and happiness for individual citizens. Plato (2007) believed that the path to follow is one that aims to achieve the good life for people. Leadership should help people reach such a goal which society ought to facilitate. Aristotle (2012) expressed the view that all actions should aim to produce good outcomes. Knowing the right goal is important for people's quality of life. Thus, he stated that people should strive for eudaimonia, meaning that all of us, both as individuals and in organisations, should attempt to develop our unique talents and exploit our resources as best we can to create a good life (Handy, 2006). Consequently, leadership should focus upon attaining certain objectives other than simply generating material wealth (Aristotle, 2012). Classical philosophy therefore supports the idea that leadership should expand beyond the material to include social and spiritual goals. Ciulla (2011) thus argues that many of the classical philosophers believed that a leader was only a leader when other people said so. Therefore, the term leader has a built-in normative aspect; leaders only lead if they meet certain criteria and / or ethical standards of their followers. 
This legacy remains valid to the present day when people assess whether or not leaders are good.

Thus, good leadership may be understood as the leader's ability to make others follow voluntarily. This is in agreement with the summative opening sentence of Rousseau's (2006) major work, The Social Contract. "Man is born free, and everywhere he is in chains" (p.909). Such voluntariness requires the leader to possess good qualities and characteristics that enable followers to free themselves from their "chains" and act with autonomy. Subsequently, a supplementary answer to what constitutes good leadership is that goals should be shared, that is, the goals of the leader and his or her followers should be identical, expressed as good goals, materially, socially, and spiritually.

\section{One Expression of Leadership Goodness: The "Feel-Good" Phenomenon}

We might ask, "Does the legacy of the classical philosophers have any relevance for society and workplaces today?" In much of the current literature, authors write about leadership as something good (e.g. Alvesson et al., 2017). Leadership is used, often unconsciously, as a hallelujah word. Leaders do good things, we might assume. They generate value in businesses, operate schools in the students' best interests, and manage hospitals so that patients receive the care they need. They help people and organisations to develop. In the leadership literature, we would not read much about dictators and terrorists, such as Hitler, Mussolini, Stalin, Osama bin Laden, and the Islamic State's Abu Bakr al-Baghdadi. These men were also leaders who attracted many followers and generated extraordinary results (albeit not for the good). On the other hand, the literature provides an abundance of success stories about business leaders, technology entrepreneurs, and leading politicians. However, we do not learn much about the deeds of tyrants as the vast majority of the leadership literature portrays leaders as good people with good intentions (Bass \& Steidlmeier, 1999). In response to the above-mentioned question, the legacy of the classical philosophers has been well preserved, and Ciulla (2011) is certainly correct in saying that leadership embodies normative expectations.

It would be fine if such an understanding of leadership reflected reality, but it does not. This is problematic. First, other perspectives of leadership fade into the background, crowded out by the volume of "feel-good" stories and nicely-packaged leadership concepts. Second, the understanding that leadership is always good is self-reinforcing, and many proponents look for facts that confirm preconceived assumptions. Third, the search for good leadership creates unrealistic expectations of what leaders can achieve. Fourth, many leaders are not effective in exercising leadership so that we cannot say that leadership is always good. It is not because leaders do not want to lead effectively, but there are too many barriers preventing them from attaining their goals.

Since leaders have the power and the opportunity to make a difference in people's lives, we certainly want them to be good persons. This desire leads some people to attribute good qualities to leaders. Leaders are given the right to govern others; therefore, many people cling to the hope that leaders are good individuals who want to achieve the best for society. In other words, people need that illusion. The vast majority of leaders are most likely good people who do the best they can; however, the wish to identify goodness in leaders and leadership sometimes clouds reality. This becomes evident if we look at the content of many leadership courses or review the bulk of the leadership literature, which often writes in glowing terms about the accomplishments of "great" men and women. Leaders who have achieved something outstanding are ascribed with good qualities. Of course, they must have accomplished something; they must have created results. Consider Julius Caesar, the Roman statesman who played a crucial role in the transformation of the 
Roman Empire from a republic to a monarchy. According to Napoleon (2018), anyone who wishes to become a great leader should study Julius Caesar. Caesar is often credited with possessing exceptional leadership skills (Bjartveit, 2019). However, Caesar's biography was mainly self-authored. It may very well be the case that he was a good person, a leader with great talents, that is, one-in-a-million, but there is also reason to be sceptical. Undoubtedly, he achieved results. However, the flipside is just as certain: his accomplishments came at a cost. If we had as much access to the accounts of the soldiers in Caesar's army or of the ordinary people who lived in Rome during his rule, the picture would undoubtedly be more nuanced. Indeed, leadership should promote the good of society and people. Moreover, leaders should follow Aristotle's (2012) advice that it is not enough to engage in the right actions; they must come from the right inner state. Few people would disagree that love is an important motivator as are the search for knowledge, insight, understanding, and justice - ideals that classical philosophy sets as high standards. If leaders led in the way prescribed by the philosophers, most societies, organisations, and individuals would ostensibly be more capable of achieving good goals.

\section{However, Leaders Do Not Always Do What They Ought To Do}

Leaders do not always act how they should. Power can lead to dominance, abuse, and destructive actions. The bulwark that philosophy has constructed to counter abuses of power is ethics. In classical philosophy, the capacity for ethical reflection is thus an important quality for a leader. Plato recommended that leaders should be practical philosophers and use philosophy as an aid to their own and others' self-development. In this regard, the tool is ethics, the practice of systematic reflection on what is right and wrong in interactions among people. Ethics should help leaders make good decisions; ethics employs moral philosophy in a quest to find the answer to what is good. Accordingly, ethical reflection was the classical philosophers' response to how someone could know whether or not something was good, including whether or not certain leadership practices were good.

Some of the ideas in positive psychology can be traced back to classical philosophy. Among other things, positive psychology re-examines moral philosophy and is concerned with what is good in people. The discipline focuses on an examination of virtues, which may be viewed as a reaction to the increasing immorality, greed, short-sightedness, and selfishness in society; consequently, there is an increased interest in identifying timeless, universal qualities. This interest may also be explained by the growing uncertainty and rate of change in today's society. This has led to enhanced awareness that it is the individua/ who has the capability to make a difference, not necessarily systems and structures. This, in turn, has resulted in a stronger focus on highlighting and examing the good in people. In this context, a leader's good qualities and skills are important in the sense that he or she sets an example that other people can follow (Krokan \& Strand, 2010; Peterson \& Seligman, 2004). The god Krishna says something similar to Prince Arjuna, when he gives advice concerning the problems that the prince will face before a major battle, as recorded in the 5000-year-old Hindu sacred text Bhagavad Gita: "People follow the noble ones. People follow the standards created by them" (Yogi, 1969: verse 3:21).

The large volume of leadership research is thus relatively clear, though with variations, on what creates good leadership. Although it is possible to gain insights into what constitutes good leadership, many studies indicate that good leadership is not always practised in the workplace (Ennova, 2015 Gallup, 2013; Hogan, 2006; Hogan \& Kaiser, 2005; Telfer, 2013; TUC, 2012). Work environment surveys show the same trend. The picture is complex, and the trends are not clear, but many employees feel that their leader should 
not be a leader and that leaders do not spend much time on what can be termed leadership-related tasks (Ennova, 2015).

There are also many indications that poor leadership, even bullying, is the largest source of employee dissatisfaction, leading to increased sick leaves and staff resignations (Ennova, 2015). These types of surveys obviously have many sources of error and they do not necessarily provide a complete picture of the conditions in the workplace. Another part of the explanation is that we live in times when many employees have high - too high expectations of their leaders, their workplaces, and themselves. However, there is still cause for concern. Although research provides us with knowledge about how to lead, it seems that many leaders do not perform well. Many employees feel undervalued and faceless and think that leaders are unable to make decisions or give clear directions; moreover, they focus too much on details, fail to deal with conflicts and difficult situations, communicate poorly, and do not adress breaches in the regulations. Some leaders also abuse power, dominate their subordinates, and resort to mastering suppression techniques.

Thus, why do leaders not always lead that well? Undeniably, good leadership is difficult. Leaders simply do not always exercise good leadership because of many barriers to it such as environmental, organisational, and personal obstacles. Most leaders operate under demanding conditions. They have to function in indistinct roles and survive hectic workdays with cross-pressures, resource scarcity, conflicts, stress, and friction. Leaders at the lower, middle, and top levels, in both private and public sectors, often face high performance pressures, hectic and long work days, fast-paced tasks, uncertainty, pressure, restructuring requirements, and emotionally-charged situations that they have to deal with, as well as difficulties that need to be ameliorated. They also need to manage scarce resources and tight budgets. They have to attend to many stakeholders and may experience conflicts between goals and values. They need to balance stability with change, short-term goals with long-term visions, and daily operations with strategic new initiatives. Therefore, few leaders are equipped with the knowledge, skills, and abilities needed to cope with such a wide range of tasks and challenges.

Nonetheless, it is a reasonable assumption that most leaders are suited to the positions they hold. However, in some cases, the leaders themselves pose barriers to good leadership. It should not be this way, but it is often the situation. Sometimes, leaders do not perform their jobs well because they fail to do what they should. This is not necessarily due to inflexibility or ignorance, but to shortcomings and weaknesses that are characteristic of many leaders. It may be the case that the leaders lack enough time, energy, or capacity to lead. This is not unusual, and this explanation is frequently given when leaders are asked why they are not leading well. It may be because they do not understand what needs to be done, do not comprehend the situation they are in, do not see the big picture, and lack awareness of the employees' situations and needs. It may also be due to the lack of self-insight and experience as well as to insufficient cognitive and emotional abilities. Leaders may not possess the courage to perform what needs to be done or lack the resolve to tackle demanding problems, grapple with difficult situations, and deal with conflicts, disagreements, and opposition. This may be explained by many leaders' reluctance to deal with emotionally-charged issues as well as their lack of the proper training, confidence, and strength required to handle such situations. It may also be explained by the fact that power corrupts and that leaders often abuse power. Yet another reason may be that leaders focus too much on their own interests, award themselves with benefits, and operate with too great a gulf between theory and practice. 
These are often due to selfishness and lack of awareness of ethical boundaries, as well as own values.

\section{“Good Enough" Leadership}

Many of the issues I have discussed in the preceding sections is the result of human fallibility - both individually and collectively in organisations. Humans can achieve the most incredible results, but they are also fallible. In his novel, The Log from the Sea of Cortez, the Nobel prize-winning American author John Steinbeck (1951, p. 80) wrote, [ ] ] here is a strange duality in the human which makes for an ethical paradox. Steinbeck stated that we humans share universal good and bad qualities: good qualities, such as wisdom, tolerance, altruism, generosity, and humility, and bad qualities, such as malice, greed, and egoism. In some circumstances, the author claimed, it can seem that the people with bad qualities are those who do well, while those with good qualities fail to succeed as they should. According to Steinbeck (1951, p. 263): Perhaps no other animal is so torn between alternatives. Man might be described fairly adequately, if simply, as a two-legged paradox.

The Latin phrase errare humanum est translates to "to err is human." The human brain's capacity to solve problems is amazing, but it is also prone to error and its self-insight is limited, especially concerning its own sources of error. The brain is easily deceived. It takes shortcuts which affect memory, decisions, and behaviour. Such processing errors have been researched in several disciplines such as cognitive psychology and behavioural economics, and have given rise to theories of limited rationality, cognitive dissonance, attribution, and heuristics (Baron, 2000; Gilovich, 1993; Hardman, 2009; Kahneman, 2011; Kahneman et al., 1982; Plous, 1993; Schacter, 1999; Sutherland, 2007). Generally, the errors are due to information overload, the need to act quickly, and limitations in memory and processing capacity as well as the influence of emotions and social pressures. When people make decisions, they rely too much on incomplete information. They reinforce collective attitudes to avoid being at odds with the group to which they belong and they make risky choices to evade anything that they think is negative. To cite two more examples, people also tend to allow themselves to be influenced by authority figures and support those whom they regard as belonging to their group.

Therefore, people are not just rational, utility-maximising individuals; they are affected by needs, internal tensions, defence mechanisms, and emotions such as anxiety, insecurity, fear, anger, and pain. These factors that affect people's thinking do not receive much attention in the leadership literature (Kets de Vries \& Balazs, 2013). Good intentions are fine but are of little help when subconscious processes pull leaders in different directions. This relates to Freud's (1923) thesis about the struggle between the conscious and the subconscious. Disciplines such as psychodynamics, psychoanalysis, psychotherapy, developmental psychology, and neuropsychology are all about how the subconscious can influence behaviour (Bowlby, 1969; Emde, 1981; Mahler et al., 1975; McDougall, 1985; Winnicott, 1975). Much of the regulation of people's behaviour occurs in the subconscious mind. It can give rise to reactions and learned patterns that can lead to flight-or-fight reactions, withdrawal, disengagement, and the avoidance of difficult social situations.

People are fallible, and fallible people work for error-prone organisations. Fallibility at the individual level is aggregated up to the system level but is also kept in check by institutional norms, values, and collective practices. An organisation includes structure, rules, follow-up procedures, and sanctions - in sum, an established order or a social system designed to achieve goals (Ahrne \& Brunsson, 2011; Etzioni, 1964). Organisations are thus ordered according to design, form, structure, and the processes that lead to human interaction 
(Tsoukas \& Chia, 2002). It is usually assumed that collaboration in organisations is primarily rational and knowledge based. However, Alvesson and Spicer (2012) point out the limitations of rationality in organisations which they claim is often due to the exercise of power and internal political games. Morgan (1986) thus lays out eight metaphors for organisations - relating, among others, to the fallibility of organisations - including the metaphor "psychological prisons," which describes the unconscious processes in organisations. Morgan's point of departure is that organisations must be understood as complex, richly faceted, and paradoxical (Jørgensen et al., 2004). He argues that organisations are socially-constructed realities that acquire power over their members to such an extent that these people are influenced, governed, and hampered in their choices and activities (Morgan, 1986).

Thus, barriers to an effective interaction exist in organisations. Interaction in organisations is therefore not only a product of rational actions; it is also a consequence of errors, resistance, ambivalence, cynicism, lack of trust, and internal political games (Bryman \& Lilley, 2009; Dawson, 2003; Naus et al., 2007). Additionally, organisations are influenced by their environment in the same way that they affect it. This symbiotic relationship is characterised by resource transactions, exchange relations, influence, legitimacy, and uncertainty (Karp, 2014). Therefore, forces in the environment affect interactions in organisations which may be forces that are stronger than the actions of individuals (Mukunda, 2012; Pfeffer \& Salancik, 1978). Such forces tend to trump even the most determined and will-powered individual (Karp, 2015). People create the structure in which they work, but concomitantly are influenced by the same structure (Giddens, 2001). Thus, the idyllic image of rational and structured organisations that is so often portrayed in the bulk of the leadership literature is at odds with the reality described above.

Good leadership is thus an ideal that is difficult to achieve. Leadership is a romanticised concept, and there is every reason to narrow the gap between what is perceived as ideal and the reality that most leaders face (Meindl et al., 1985). Random factors, luck, arbitrary movements in the market, and internal relationships in organisations are also part of the equation that determines whether or not leaders succeed. There is every reason to be sceptical when hearing rumours about the success or failure of leaders or when reading unconfirmed accounts of great leadership without substance, wrapped up in jargon, clichés, and empty words. The ideal is perhaps "good enough" leadership (Karp, 2019)? Good enough in this context means lowering expectations regarding what leaders can accomplish and how quickly they can achieve something - the extent to which they can develop and change organisations as well as other people and themselves.

Can leaders accept good enough as satisfactory? Can and should they accept their own fallibility but at the same time be good enough in others' eyes and their own? Seneca (1881) provides the recipe when he says that people must reconcile themselves with being imperfect, thrive on their mistakes, and be satisfied with being good enough. Leaders are also fallible. They may also feel insecure and uncertain and have their doubts, negative thoughts and good or bad days at work. The ancient Roman emperors had a solution. When an emperor returned to Rome after a successful military campaign, he would ride on a chariot through the streets lined with applauding crowds. Behind him, on the chariot, a slave was employed to constantly whisper in his ear, Memento mori ("Remember that you will die"). Some leaders are tempted to set the targets so high that they fail to achieve their goal. They include the organisation that they lead in the race to reach unattainable goals and collapse before they reach the finish line. Most likely, many people would have had a much better life if, while developing their abilities, they were able to reconcile themselves to the fact that they had limitations. This also applies to leaders. Most employees want to 
be led by a person, not a superhuman. Of course, there are risks associated with a good enough strategy. However, a greater risk is associated with leaders who distance themselves too much from the reality and the challenges faced by the employees and the organisations that they lead.

\section{In Search of Good Leadership}

Classical philosophers believed that people would voluntarily follow a good leader towards good goals. However, in modern leadership research, theorists have increasingly abandoned the concept of goodness. Instead, they believe that leadership should be effective, not "just" good. Certainly, the goodness principle is present in many accounts of what constitutes ideal types of leadership. It is common to assert that a leader's values, ethics, and morals are important and that a relationship exists between these and the organisation's ethical behaviour. Many organisations also have values or ethical guidelines for leaders and employees and meet the demands of increased corporate social responsibility. International organisations and institutions are also very concerned about what constitutes a good society, as evidenced by the UN Declaration of Human Rights and the Earth Charter. However, within the field of leadership, "goodness" has become an isolated topic.

As a whole, the leadership field has increasingly focused more on effectiveness. Goodness is implicit, and we often assume that leadership is good, but its purpose has changed. The reason why leadership has to be effective can be explained by the growth of capitalism, which has led to the expectation that leaders should use resources efficiently so that goals can be achieved. Consequently, a greater degree of instrumentality has crept into the field of leadership research. Leadership should have a clear purpose - it is not enough to develop good people and good societies; concrete, measurable results have to be delivered. Of course, people and organisations should still be developed, but mainly as means to reach certain goals. Leadership has become a tool. The development of leadership research over the last 100 years supports this perspective. Research objectives have increasingly focused on creating models of effective leadership. The models often emphasise the type of optimal leadership behaviour that will ensure effective leadership; these models and associated theories are then disseminated as universal answers regarding what leaders should do. Thus, the field has become dominated by approaches and methods whose goal is to simplify complex realities by finding explanatory mechanisms regarding interpersonal interaction in organisations.

What then is really good leadership? If we believe the majority of the classical philosophers, the answer is that good leadership requires voluntary followership towards good goals. Modern leadership research focuses more on the aspect of effectiveness, emphasising how leaders can exert influence, while dealing with the concept of goodness as a sub-point. The large volume of research highlights the attributes, abilities, and qualities that an effective leader possesses or should develop. Additionally, attention is paid to the leader's abilities to be a role model, create meaning, and support, help and make employees feel valued, while providing them with intellectual stimulation and exciting work assignments. Other research emphasises what leaders do, how effective they are in their leadership work, and how they cope with contextual and organisational framework conditions determine whether or not they exercise good leadership over time. Another proposition is that specific attributes, abilities, and qualities of a leader do not determine whether leadership succeeds or fails, but the context, people, and relationships are the decisive factors. A more challenging view is that the claim implied in the question is that there is no such thing as good leadership. Good leadership is not a real phenomenon, but a construct 
that has been invented to ascribe importance to leaders and leadership so as to cultivate elitism, which is then reinforced by the accumulation of research about the construct. $A$ final argument is that leaders in any case are rarely able to practise good leadership because of all the barriers and restrictions, such as environmental, organisational, and personal obstacles. People are fallible; so are leaders. Many people and leaders themselves have too high expectations of what leadership can achieve. Perhaps the answer to the question of what constitutes good leadership is that leadership should be good enough, without leaders lowering the requirements of how they treat other people or without taking ethical shortcuts.

\section{References}

Ahrne, G. and Brunsson, N. (2011). Organization outside organizations: The significance of partial organization. Organization, 18 (1), 83-104.

Alvesson, M. (2019). Waiting for Godot: Eight major problems in the odd field of leadership studies. Leadership, 15 (1), 27-43.

Alvesson, M. and Spicer, A. (2012). A stupidity-based theory of organizations. Journal of Management Studies, 49 (7), 1194-1220.

Alvesson, M., Blom, M. and Sveningsson, S. (2017). Reflexive leadership. Organising in an imperfect world. London: Sage.

Aristotle (2012). Nicomachean ethics. Translated by Robert C. Bartlett and Susan D. Collins. Chigaco: University of Chicago Press.

Baron, J. (2000). Thinking and deciding. 3rd ed. New York: Cambridge University Press.

Bass, B. and Steidlmeier, P. (1999). Ethics, character, and authentic transformational behavior. The Leadership Quarterly, 10 (2), 181-217.

Bjartveit, S. (2019). Hva ledere kan lære av Cæsar. Dagens Næringsliv, 8 March 2019. Downloaded from: https://www.dn.no/innlegg/julius-casar/ledelse/roma/hva-leder e-kan-lare-av-casar/2-1-560283. Accessed: 24 April 2019.

Bowlby, J. (1969). Attachment and loss. New York: Basic Books.

Brunstad, P. O. (2009). Klokt lederskap mellom dyder og dødssynder. Oslo: Gyldendal Akademisk.

Bryman, A. and Lilley, S. (2009). Leadership researchers on leadership in higher education. Leadership, 5 (3), 331-346.

Ciulla, J. B. (2011). Handmaiden and queen: What philosophers find in the question: "what is a leader?" In M. Harvey and R. E. Riggio (eds.), Leadership studies. The dialogue of disciplines. 54-65. Cheltenham: Edward Elgar Publishing.

Cleary, T. (1989). Zen lessons - The art of leadership. Boston: Shambhala Publications.

Cleary, T. (1990). The book of leadership \& strategy. Boston: Shambhala Publications.

Dawson, P. (2003). Reshaping change: A processual perspective. London: Routledge. 
Emde, R. N. (1981). Changing models of infancy and the nature of early development: Remodelling the foundation. Journal of American Psychoanalytical Association, 29, 179-219.

Ennova. (2015). Global employee and leadership index 2015. Norway 2015. 16th ed. Oslo: Ennova.

Etzioni, A. (1964). Modern organizations. Englewood Cliffs, NJ: Prentice-Hall.

Forsth, L.-R. (2002). Hva er lederskap? Og hva er godt lederskap? Thesis in philosophy. Oslo: University of Oslo.

Freud, S. (1923). The ego and the id. SE, 19, 1-66.

Gallup. (2013). The state of the American workplace: Employee engagement insights for U.S. business leaders. Downloaded from: www.gallup.com/services/176708/stateamerican-workplace.aspx. Accessed: 24 March 2015.

Giddens, A. (2001). Sociology. 4th ed. Cambridge: Polity Press.

Gilovich, T. (1993). How we know what isn't so: The fallibility of human reason in everyday life. New York: The Free Press.

Handy, C. (2006). Philosopher leaders. In F. Hellelbein and M. Goldsmith (eds.), The leader of the future. Visions, strategies, and practices for the new era.131-139. San Francisco: Jossey-Bass.

Hardman, D. (2009). Judgment and decision making: Psychological perspectives. Hoboken, New Jersey: Wiley-Blackwell.

Hogan R. (2006). Personality and the fate of organizations. Hillsdale, NJ: Erlbaum.

Hogan, R. and Kaiser, R. (2005). What we know about leadership. Review of General Psychology, 9 (2), 169-180.

Jørgensen, S.-H., Hoff-Leirvik, E., and Paulsen, T. (2004). Mulighetens reservoar: Om energiflyt i organisasjoner. KUNNE Nedtegnelse $N$ 01/04. Trondheim: SINTEF Teknologi og samfunn.

Kahneman, D. (2011). Thinking, fast and slow. New York: Farrar, Straus and Giroux.

Kahneman, D., Slovic, P. and Tversky, A. (1982). Judgment under uncertainty: Heuristics and biases. Cambridge, Storbritannia: Cambridge University Press.

Karp, T. (2010). Ledelse i sannhetens øyeblikk. Om å ta lederskap. Oslo: Cappelen Damm Akademisk.

Karp, T. (2014). Endring i organisasjoner. Ideologi, teori og praksis. Oslo: Cappelen Damm Akademisk.

Karp. T. (2015). Is Willpower Important for Acts of Leadership? Leadership. 11(1), 2035.

Karp, T. (2019). God nok ledelse. Hva ledere gjør i praksis. Oslo: Cappelen Damm Akademisk.

Kets de Vries, M. and Balazs, K. (2013). The shadow side of leadership. In A. Bryman, D. Collinson, K. Grint, B. Jackson and M. Uhl-Bien (eds.), The SAGE handbook of leadership, 380-392. London: Sage. 
Krokan, M. and Strand, M. (2010). Styrke i sannhetens øyeblikk. Sammenheng mellom lederes personlige egenskaper og hvordan de håndterer et definerende øyeblikk. Bachelor thesis. Oslo: Oslo School of Management.

Machiavelli, N. (1992). The Prince. New York: Dover Publications.

Mahler, M. S., Pine, F., and Bergman, A. (1975). The psychological birth of the human infant. New York: Basic Books.

McDougall, J. (1985). Theaters of the mind. New York: Basic Books.

Meindl, J. R., Ehrlich, S. B., and Dukerich, J. M. (1985). The romance of leadership. Administrative Science Quarterly, 30 (1), 78-102.

Morgan, G. (1986). Images of organization. Thousand Oaks, CA: Sage.

Mukunda, G. (2012). Leaders don't matter (most of the time). Harvard Business Review, July-August 2012, 15-16.

Napoleon (2018). Chronicles of Caesar's Wars. Transalated by Arshan Barzani, preface by Louis Joseph Marchand. Independently published.

Naus, F., van Iterson, A. and Roe, R. (2007). Organizational cynicism: Extending the exit, voice, loyalty, and neglect model. Human Relations, 60 (5), 683-718.

Peterson, C. and Seligman, M. E. P. (2004). Character strengths and virtues. A handbook and classification. Oxford: Oxford University Press.

Pfeffer, J. and Salancik, G. (1978). The external control of organizations: A resource dependence perspective. New York: Harper and Row.

Plato. (2007). The Republic. Translated by Translated by Deesmond Lee with an Introduction by Melissa Lane. London: Penguin Books Ltd.

Plous, S. (1993). The psychology of judgment and decision making. New York: McGrawHill.

Rousseau, J. J. (2006). The Social Contract. London: Penguin Books Ltd.

Schacter, D. L. (1999). The seven sins of memory: Insights from psychology and cognitive neuroscience. American Psychologist, 54 (3), 182-203.

Seneca (1881). Seneca's morals of happy life, benefits, anger and clemency. Translated by Roger L'Estrange. Chicago: Belford Clarke \& Co.

Seneca, L. A. (1982). Skrifter. Oslo: Dreyers Forlag.

Steinbeck, J. (1951). The Log from the Sea of Cortez. London: Penguin Books.

Sutherland, S. (2007). Irrationality. London: Pinter and Martin.

Telfer, J. (2013). Bosses behaving badly. Training Journal, March 2013, 44-48.

Tsoukas, H. and Chia, R. (2002). On organizational becoming: Rethinking organizational change. Organisation Science, 13 (5), 567-582.

TUC. (2012). What do workers want? YouGov poll for the TUC, August 2008.

Winnicott, D. W. (1975). Through paediatrics to psychoanalysis. New York: Basic Books.

World Economic Forum. (2016). The future of jobs. Employment, skills and workforce strategy for the Fourth Industrial Revolution. Global Challenge Insight Report. 
Geneva: World Economic Forum. Downloaded from: http://www3.weforum.org/ docs/WEF_Future of Jobs.pdf. Accessed: 9 November 2019.

Yogi, M. M. (1969). On the Bhagavad-Gita: A new translation and commentary. Baltimore, MD: Penguin.

Yukl, G. (2013). Leadership in organizations. 8th ed. Upper Saddle River, NJ: Pearson.

\begin{abstract}
About the Author
Tom Karp is a professor in leadership and management at Kristiania University College, Oslo, Norway, and adjunct professor at Nord University Business School and Inland Norway University of Applied Sciences. He has a PhD in change management, a master's degree in leadership, a master's degree in engineering, and a diploma in economics. Prior to his academic career, Dr. Karp held top-level positions within the industry, led consultancy companies, and co-initiated entrepreneurial start-ups. His research interests include leadership, managerial work in practice, change processes, leadership development, and personal mastery. He has published five books, chapters in many others, as well as a large volume of scientific publications in international journals. He may be contacted at: tom.karp@kristiania.no.
\end{abstract}

